\title{
Fatty Acid Uptake by Isolated Rat Heart Myocytes Represents a Carrier-mediated Transport Process
}

\author{
Wolfgang Stremmel \\ Department of Medicine, University Clinics of Düsseldorf, 4000 Düsseldorf, Federal Republic of Germany
}

\begin{abstract}
The mechanism by which fatty acids enter cardiomyocytes is unclear. Therefore, the influx kinetics of $\left[{ }^{3} \mathrm{H}\right]$ oleate into isolated rat heart myocytes were examined. Cells were incubated at $37^{\circ} \mathrm{C}$ with $\left[{ }^{3} \mathbf{H}\right]$ oleate bound to albumin in various molar ratios and the initial rate of uptake $\left(V_{0}\right)$ was determined as a function of the unbound oleate concentration in the medium. $V_{0}$ was saturable with increasing oleate concentrations incubated $\left(K_{\mathrm{m}} 78 \mathrm{nM} ; V_{\max } 1.9 \mathrm{nmol} \times \mathrm{min}^{-1}\right.$ per $10^{6}$ cells $)$ and temperature dependent with an optimum at $37^{\circ} \mathrm{C}$. Furthermore, binding of $\left[{ }^{3} \mathrm{H}\right]$ oleate to isolated plasma membranes of cardiomyocytes was saturable, revealing a $K_{\mathrm{D}}$ of $\mathbf{4 2} \mathrm{nM}$, and was inhibited by heat denaturation or trypsin pretreatment of the membranes. From these membranes a single $40-\mathrm{kD}$ protein with high affinity for a variety of long chain fatty acids was isolated. With a monospecific antibody to this membrane protein, binding as well as cellular influx of $\left[{ }^{3} \mathrm{H}\right]$ oleate was selectively inhibited. These data indicate that at least a portion of myocardial fatty acid uptake is mediated by a specific membrane protein.
\end{abstract}

\section{Introduction}

Although fatty acids are the preferred substrates for energy production of the heart, their cellular uptake mechanism is still unclear. The lipophilic character of fatty acids suggests that they might diffuse directly through the phospholipid bilayer of the plasma membrane. However, the recent identification of a membrane-associated fatty acid transport system in hepatocytes (1-3) led to the hypothesis that myocardial fatty acid uptake might also be mediated by such a carrier. Therefore, in the present study the influx kinetics of a representative long chain fatty acid, $\left[{ }^{3} \mathrm{H}\right]$ oleate, into isolated cardiomyocytes was determined to evaluate whether uptake occurs by a passive diffusional process or reveals criteria of a carrier-mediated transport mechanism. Furthermore, it was examined whether myocardial plasma membranes also contain a specific fatty acid binding protein, which mediates the influx of fatty acids into the cells. The identification of such a carrier mediated uptake system could be of biologic significance, since it might represent a site of metabolic and hormonal control of fatty acid metabolism.

Received for publication 2 July 1987 and in revised form 10 September 1987.

J. Clin. Invest.

(C) The American Society for Clinical Investigation, Inc.

0021-9738/88/03/0844/09 \$2.00

Volume 81, March 1988, 844-852

\section{Methods}

Materials. $\left[9.10-{ }^{3} \mathrm{H}\right]$ Oleic acid; $\left[1-{ }^{14} \mathrm{C}\right]$ arachidonic acid; $\left[9.10-{ }^{3} \mathrm{H}\right]-$ palmitic acid; $\left[{ }^{14} \mathrm{C}\right]$ linoleic acid; L- $\alpha$-1-palmitoyl-2- $\left[1-{ }^{14} \mathrm{C}\right]$ oleoylphosphatidylcholine; cholesteryl $\left[1-{ }^{14} \mathrm{C}\right]$ oleate; $3-O-\left[{ }^{14} \mathrm{C}\right.$-methyl]-Dglucose; $\mathrm{D}-\left[3-{ }^{3} \mathrm{H}\right]$ glucose; and Aquasol were from New England $\mathrm{Nu}-$ clear, Dreieich, West Germany.

Collagenase (type I) was from Worthington Biochemicals, Freehold, NJ. Bovine serum albumin (fraction V, essentially fatty acid free), trypsin (type XIII), phloridzin, oleic acid, Hepes, ouabain, and Triton X-100 were from Sigma Chemie GmbH, München, West Germany. SDS, polyacrylamide and Bio-Beads SM2 were from Bio-Rad, München, West Germany; AH-Sepharose 4B from Pharmacia, Freiburg, West Germany; rabbit antiserum against whole rat serum and rat albumin from Cappel Laboratories, Cochranville, PA. Fluorescein isothiocyanate-conjugated swine anti-rabbit antiserum was from Dako, Copenhagen, Denmark. All reagents were analytical grade and doubly distilled, deionized water was used in all experiments. Glassware was acid washed.

Sprague-Dawley rats were fed a standard Altromin 1314 diet and were obtained from the Zentralinstitut für Versuchstiere, Hannover, West Germany.

Preparation of isolated cardiomyocytes. Calcium tolerant cardiomyocytes were isolated from 12-wk-old female Sprague-Dawley rats following the procedure of Powell et al. (4) with minor modifications (5). The cell pellets obtained were washed three times in the incubation medium containing $125 \mathrm{mM} \mathrm{NaCl}, 2.6 \mathrm{mM} \mathrm{KCl}, 1.2 \mathrm{mM} \mathrm{KH}_{2} \mathrm{PO}_{4}$,

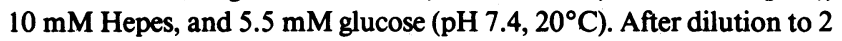
$\times 10^{6}$ cardiomyocytes $/ \mathrm{ml}$, the cell suspensions were immediately used for uptake studies.

The viability of the cell preparations were routinely tested before and after each series of incubation experiments. Morphologic evaluation was performed using a phase-contrast microscope (Zeiss, Oberkochen, West Germany) at magnifications of 50 - and 128 -fold. The preparations were considered suitable when $>90 \%$ of the cells excluded trypan blue and $>70 \%$ of these trypan blue negative cells revealed a rod-shaped morphology with a clear transparent stroma and distinct cross striations (6). Additional criteria for viability were based on the intracellular $\mathrm{K}^{+}$-concentration estimated by atomic absorption spectroscopy, the ATP content (7), as well as the release of lactate dehydrogenase $(\mathrm{LDH})^{1}(8)$ and creatine phosphokinase (CPK) $(9)$ into the medium.

Preparation of $\left[{ }^{3} \mathrm{H}\right]$ oleate working solutions. Tracer amounts of $\left[{ }^{3} \mathrm{H}\right]$ oleate were mixed with measured quantities of nonradioactive oleic acid in chloroform, dried under a $\mathrm{N}_{2}$ gas stream, and dissolved in $0.2 \mathrm{ml}$ of $0.1 \mathrm{~N} \mathrm{NaOH}$. Bovine serum albumin dissolved in incubation medium was added to the oleate $/ \mathrm{NaOH}$ solution to obtain the desired oleate/albumin molar ratio, the $\mathrm{pH}$ was immediately adjusted to 7.4, and the oleate/albumin solution was diluted to its final working concentration. In such $\left[{ }^{3} \mathrm{H}\right]$ oleate/albumin solutions the concentration of unbound fatty acids was calculated by the stepwise equilibrium constant method of Wosilait and Nagy (10), using the dissociation constants for the oleate/albumin complex reported by Spector et al. (11).

1. Abbreviations used in this paper: CPK, creatine phosphokinase; LDH, lactate dehydrogenase. 
Cellular uptake of $\left[{ }^{3} \mathrm{H}\right]$ oleate. $125 \mu \mathrm{l}$ of the isolated cardiomyocyte suspension $\left(2 \times 10^{6}\right.$ cells $\left./ \mathrm{ml}\right)$ were incubated with $\left[{ }^{3} \mathrm{H}\right]$ oleate bound to albumin in polypropylene tubes at a final volume of $1 \mathrm{ml}$ incubation medium (shaking waterbath, $37^{\circ} \mathrm{C}$ ). After certain incubation periods 200- $\mu \mathrm{l}$ sample aliquots were pipetted into $3 \mathrm{ml}$ of an ice-cold $0.5 \%$ albumin solution to stop cellular influx and efflux, and to remove surface bound fatty acids. After gentle mixing for $2 \mathrm{~min}$ on ice the sample was pipetted onto the center of a GF/C filter $(24 \mathrm{~mm}$; Whatman Inc., Clifton, $\mathrm{NJ}$ ) at a rate equal to the rate of filtration under 50 mmHg vacuum pressure using a filtration apparatus (model $7 \mathrm{H}$; Hoefer Scientific, San Francisco, CA). The cells were washed with $5 \mathrm{ml}$ of the $0.5 \%$ albumin solution $\left(4^{\circ} \mathrm{C}\right)$ and, thereafter, with $20 \mathrm{ml}$ incubation medium. Washing with more of the stop solution did not change the radioactivity remaining on the filter. The filters were placed in scintillation vials, $10 \mathrm{ml}$ of Aquasol were added, and the radioactivity was determined in a 1217 Rackbeta liquid scintillation counter (LKB-Wallac, Turcu, Finland). Nonspecific association of radioactivity to filters and cells was determined for each experimental circumstance by adding the cold stop solution before the addition of corresponding aliquots of cells and $\left[{ }^{3} \mathrm{H}\right]$ oleate working solutions. After vacuum filtration of the samples and washing the filters with the stop solution, radioactivity was measured as described. $\left[{ }^{3} \mathrm{H}\right]$ Oleate nonspecifically absorbed to filters and cells was routinely determined and subtracted from values measured in the corresponding incubation experiments. This blank always constituted $<2 \%$ of the incubated radioactivity. All incubations were performed in triplicate and all observations were confirmed with at least three separate cell preparations.

The fraction of $\left[{ }^{3} \mathrm{H}\right]$ oleate incorporated into cellular lipids and the amount oxidized to $\mathrm{CO}_{2}$ during the course of uptake was determined as earlier described (1).

Further characterization of $\left[{ }^{3} \mathrm{H}\right]$ oleate transport. In studies in which the effect of sodium depletion on uptake was examined, $\mathrm{NaCl}$ was isoosmotically replaced by sucrose, choline chloride, $\mathrm{LiCl}$, or $\mathrm{KCl}$ in the incubation medium. First, isolated cardiomyocytes were three times washed with the corresponding $\mathrm{Na}$-free incubation medium. Thereafter the cells were incubated for $20 \mathrm{~min}$ at $37^{\circ} \mathrm{C}$ in the same Na-free buffer, before $173 \mu \mathrm{M}\left[{ }^{3} \mathrm{H}\right]$ oleate/albumin (2:1) was added and the initial rate of uptake was determined as described.

The effect of ouabain on initial rate of oleate uptake was tested by incubation of $125 \mu \mathrm{l}$ of the isolated cardiomyocyte suspension $\left(2 \times 10^{6}\right.$ cells per ml) with $125 \mu \mathrm{l} 4 \mathrm{mM}$ ouabain in incubation medium $\left(37^{\circ} \mathrm{C}\right)$. Controls were incubated with $125 \mu \mathrm{l}$ of incubation medium alone, instead of ouabain. Thereafter $173 \mu \mathrm{M}\left[{ }^{3} \mathrm{H}\right]$ oleate/albumin (2:1) was added in presence or absence of $1 \mathrm{mM} \mathrm{CaCl}_{2}$ (final concentration in the incubation system). After each preincubation procedure in $\mathrm{Na}$-free buffer or with ouabain, viability of the cells was newly determined.

Cellular uptake of 3-O- $\left[{ }^{14} \mathrm{C}\right.$ methyl $]-D$-glucose (3-O- $\left.\left[{ }^{14} \mathrm{C}\right] \mathrm{MeG}\right)$. For evaluation of the glucose membrane transport competence of isolated cardiomyocytes, uptake kinetics of the nonmetabolizable glucose analogue $3-O-\left[{ }^{14} \mathrm{C}\right] \mathrm{MeG}$ was examined at $20^{\circ} \mathrm{C} .125 \mu \mathrm{l}$ of the cardiomyocyte suspension were incubated in $1 \mathrm{ml}$ incubation buffer in absence of glucose with increasing concentrations (1-15 mM) of 3-O$\left[{ }^{14} \mathrm{C}\right] \mathrm{MeG}$. At 5-s intervals $200-\mu \mathrm{l}$ sample aliquots were pipetted into 3 $\mathrm{ml}$ of a stop solution containing $0.2 \mathrm{mM}$ phloridzin in incubation buffer before measurement of the cell associated radioactivity by vacuum filtration (see above).

Isolation of enriched cardiac sarcolemma fractions. Enriched cardiac sercolemma fractions were prepared by the procedure of van Alstyne et al. (12) using ventricle tissue of Sprague-Dawley rats collected from several laboratories over a period of $6 \mathrm{mo}$ (stored in liquid nitrogen). For each experiment $100 \mathrm{~g}$ of ventricular tissue was used. The final membrane pellets were resuspended in $0.15 \mathrm{M} \mathrm{NaCl} / 0.02 \mathrm{M}$ Na-phosphate buffer (PBS; pH 7.4) and diluted to a protein concentration of $5 \mathrm{mg} / \mathrm{ml}$ as determined by the method of Lowry et al. (13). The sarcolemma fractions were stored at $-70^{\circ} \mathrm{C}$ until use. In aliquots of five representative preparations purity and contamination with other cell organelles was assessed by transmission electron microscopy (14) and marker enzyme determination. As membrane markers
$\mathrm{Na}^{+} / \mathrm{K}^{+}$-ATPase was measured with and without $1 \mathrm{mM}$ ouabain according to Schwartz et al. (15); $\mathrm{K}^{+}-$p-nitrophenyl phosphatase was determined as described by Skou (16) and the activity was given as the fraction that is ouabain $(1 \mathrm{mM})$ sensitive; $5^{\prime}$-nucleotidase was determined according to Mitchell and Hawthorne (17). Following other enzyme activities were determined as earlier described (18): acid phosphatase for lysosomal contamination, glucose-6-phosphatase for the microsomal fraction, and succinate-cytochrome $c$ reductase for mitochondria.

Binding of $\left[{ }^{3} \mathrm{H}\right]$ oleate to isolated plasma membranes. $4.54 \mu \mathrm{M}$ $\left[{ }^{3} \mathrm{H}\right.$ ]oleate bound to albumin in various molar ratios $(0.1: 1$ to $2: 1$ oleate/albumin) were incubated with isolated plasma membranes (100 $\mu \mathrm{g}$ membrane protein in $20 \mu \mathrm{l}$ ) in a final volume of $400 \mu \mathrm{l} \mathrm{PBS} \mathrm{(pH} \mathrm{7.4)}$ at room temperature. Heat denatured plasma membranes were prepared by incubation of a sarcolemma-fraction aliquot of $5 \mathrm{mg}$ protein in $50 \mathrm{ml} \mathrm{PBS}$ at $65^{\circ} \mathrm{C}$ for $16 \mathrm{~h}$ while continuously stirring. Thereafter this membrane suspension was concentrated by ultrafiltration (Diaflow membranes PM-10; Amicon Corp., Witten, West Germany), before again aliquots of $100 \mu \mathrm{g}$ protein per $20 \mu \mathrm{l}$ were prepared. The effect of trypsin digestion on $\left[{ }^{3} \mathrm{H}\right]$ oleate binding was determined by preincubation of $100 \mu \mathrm{g}$ plasma membrane aliquots $(20 \mu \mathrm{l})$ with $180 \mu \mathrm{l}$ of 0.1 $\mathrm{mg} / \mathrm{ml}$ trypsin and subsequent incubation with $1.816 \mathrm{nmol}\left[{ }^{3} \mathrm{H}\right]-$ oleate/albumin (1:1) in $200 \mu$ l PBS. After incubation for $10 \mathrm{~min}$, binding to the plasma membranes was assessed by a vacuum filtration assay as described above. $200 \mu \mathrm{l}$ of the incubation mixtures were rapidly vacuum filtered on Whatman GF/C glass filters $(24 \mathrm{~mm})$, which were quickly washed with $20 \mathrm{ml}$ ice-cold PBS. Washing with $>20 \mathrm{ml}$ did not change the amount of radioactivity remaining on the filter. After addition of $10 \mathrm{ml}$ Aquasol, radioactivity was measured as described above. $\left[{ }^{3} \mathrm{H}\right]$ Oleate absorption to the filters in the absence of plasma membranes was very reproducible for any given set of experimental circumstances, and constituted $<2 \%$. The $\left[{ }^{3} \mathrm{H}\right]$ oleate absorbed to the filters without plasma membranes was routinely determined and subtracted from the experimental values. To ensure that the filters did not allow significant quantities of plasma membranes to pass through, aliquots of $100 \mu \mathrm{g}$ plasma membrane protein were applied to the filters and washed with $20 \mathrm{ml}$ of PBS. As controls, identical aliquots were applied to other filters and placed directly into a test tube without washing. Protein content of both samples was found to be identical $(0.97 \pm 0.05 \mathrm{mg})$; even after trypsin pretreatment of the membranes $0.94 \pm 0.04 \mathrm{mg}$ protein were retained on the filter.

Isolation and characterization of a fatty acid binding protein from enriched cardiac sarcolemma fractions. A fraction of $300 \mathrm{mg}$ membrane proteins was solubilized with $1 \%$ (vol/vol) Triton X-100 (19). After centrifugation at $100,000 \mathrm{~g}$ for $60 \mathrm{~min}$, the detergent was removed with Bio-Beads SM 2 (19) and the solubilized protein mixture was loaded onto an oleate-agarose affinity column, which was prepared by coupling of sodium oleate to AH-Sepharose 4B with 1-ethyl-3-(3 dimethylaminopropyl) carbodiimide as previously described (19). After charging with the protein mixture, the column was extensively washed with PBS before elution with $8 \mathrm{M}$ urea was started. The eluate was dialyzed against PBS and concentrated by ultrafiltration. Aliquots of the eluted protein were used for SDS-PAGE (20) and cochromatography studies with tracer amounts of $\left[{ }^{3} \mathrm{H}\right]$ oleate, $\left[{ }^{3} \mathrm{H}\right]$ palmitate, $\left[{ }^{14} \mathrm{C}\right]$ arachidonate, $\left[{ }^{14} \mathrm{C}\right]$ linoleate, $\left[{ }^{14} \mathrm{C}\right]$ oleate ester of cholesterol, $\left[{ }^{14} \mathrm{C}\right]$ phosphatidylcholine and $\left[{ }^{3} \mathrm{H}\right]$ glucose over an HPLC column (Ultro-Pac TSK G3000 SW; LKB Instrument GmbH, München, West Germany) equilibrated with $0.1 \mathrm{M} \mathrm{NaCl}, 0.1 \mathrm{M} \mathrm{Na}$-phosphate (pH 6.8) (21).

Preparation of an antibody to the cardiomyocyte fatty acid binding membrane protein. Outbred New Zealand white rabbits were immunized with the cardiac fatty acid binding membrane protein as described (19). Presence and purity of the antibody was examined by radial double-immunodiffusion on agar plates (22) as well as by immunoblot techniques (23) with the fatty acid binding membrane protein from heart and liver, Triton X-100-solubilized rat heart plasma membranes, whole tissue homogenate of heart and liver, concentrated rat heart cytosolic proteins, rat serum albumin, and whole rat serum. The 
IgG fraction of the antiserum was prepared by standard techniques (24).

For indirect immunofluorescence studies frozen $5-\mu \mathrm{m}$ sections of rat heart as well as isolated cardiomyocytes were air-dried and then incubated for $30 \mathrm{~min}$ at room temperature with 1:50, 1:100, and 1:200 dilutions of the antiserum to the membrane fatty acid binding protein. After washing of the slides with PBS for $30 \mathrm{~min}$, fluorescein isothiocyanate conjugated swine anti-rabbit antiserum diluted 1:20 or 1:50 was added, thoroughly washed with PBS for $60 \mathrm{~min}$ and finally mounted with buffered glycerol. In the controls the antiserum was preabsorbed with the cardiac membrane fatty acid binding protein in equal dilution, or the preimmune serum was used instead of antiserum. Sections and cells were examined with a fluorescence microscope (Zeiss), employing the filter combination PB 485, FT 510, LP 520 (19).

Antibody inhibition studies. Binding of $\left[{ }^{3} \mathrm{H}\right]$ oleate to isolated rat heart plasma membranes was examined in presence of the IgG-fraction of the rabbit antiserum to the cardiac fatty acid binding membrane protein or as control in presence of the IgG-fraction of the preimmune serum. After pretreatment of the plasma membranes with increasing concentrations of the IgG-fractions in PBS for $30 \mathrm{~min}$, incubations with $\left[{ }^{3} \mathrm{H}\right]$ oleate were performed as described (final $\left[{ }^{3} \mathrm{H}\right]$ oleate concentration $4.54 \mu \mathrm{M})$.

Similarly, the effect of the antibody on influx of $\left[{ }^{3} \mathrm{H}\right]$ oleate into isolated cardiomyocytes was examined. $2 \mathrm{ml}$ of the cell suspension (2 $\times 10^{6}$ cells $/ \mathrm{ml}$ ) were incubated for $30 \mathrm{~min}$ at room temperature in gently rotating polypropylene tubes with $20-400 \mu \mathrm{g}$ of the IgG fraction of the antiserum to the cardiac fatty acid binding membrane protein or of the preimmune serum as controls. After centrifugation and washing the cells three times in medium, viability of the cells remained $>90 \%$ as determined by trypan blue exclusion and the fraction of rod-shaped cells $(>70 \%)$ did not decrease. After dilution to $2 \times 10^{6}$ cells $/ \mathrm{ml}$ uptake of $\left[{ }^{3} \mathrm{H}\right]$ oleate as well as of $3-O-\left[{ }^{14} \mathrm{C}\right] \mathrm{MeG}$ was examined as described above.

Statistical analysis. Results are given as means \pm SD. The $t$ test was used to test for significant differences among means (25). For kinetic and binding studies, a weighted least-squares fit of the individual data points to a rectangular hyperbola was performed as described previously (26). Derived kinetic parameters $\left(K_{\mathrm{m}}\right.$ and $\left.V_{\max }\right)$ as well as binding constants ( $K_{\mathrm{D}}$ and maximal binding capacity) in presence and absence of the antibody to the membrane fatty acid binding protein were tested for significant differences with a $z$-test (25). $P$ values equal to or less than 0.05 were considered significant.

\section{Results}

\section{Uptake of $\left[{ }^{3} \mathrm{H}\right]$ oleate by isolated cardiomyocytes}

Validation of methods. Similar to earlier studies with isolated hepatocytes $(1,2)$ calcium-tolerant cardiomyocytes were washed with Ca-free incubation buffer before the incubation experiments. Preparations of these isolated cardiomyocytes revealed $76 \pm 5 \%$ of rod-shaped cells with transparent stroma and clear cross-striations. $95 \pm 4 \%$ of all cells excluded trypan blue, the intracellular ATP content was $>9 \mathrm{nmol} / \mathrm{mg}$ cell protein, and loss of cellular LDH and CPK was < $15 \%$ during $2 \mathrm{~h}$ after preparation of the cells. Reexposure of these cells to 1 $\mathrm{mM} \mathrm{CaCl} / 4 \%$ albumin did not alter their viability or morphological appearance. To maintain the physiological transcellular ion gradients, particular of $\mathrm{Na}^{+}, \mathrm{K}^{+}$, and $\mathrm{Ca}^{+}$, it was essential to use the cells immediately after preparation and prevent their exposure below a temperature of $20^{\circ} \mathrm{C}$, which markedly reduces $\mathrm{Na}^{+} / \mathrm{K}^{+}$-ATPase (27). For determination of the functional integrity of the cells their uptake competence for glucose, which is known to be actively transported (28), was examined. For this purpose uptake of 3-O-[ $\left.{ }^{14} \mathrm{C}\right]$ methyl-D-glucose
(3-O- $\left.\left[{ }^{14} \mathrm{C}\right] \mathrm{MeG}\right)$ was determined. This compound is a nonmetabolizable glucose analogue, entering cardiomyocytes by the same transport system as glucose (29). It was shown that uptake of $1-15 \mathrm{mM} 3-O-\left[{ }^{14} \mathrm{C}\right] \mathrm{MeG}$ at $20^{\circ} \mathrm{C}$ was maximal and linear during the initial 20 -s incubation period, representing cellular influx. Therefore, the cellular influx rate at each concentration of $3-O-\left[{ }^{14} \mathrm{C}\right] \mathrm{MeG}$ was calculated from the slopes of the cumulative uptake curves over the initial 20-s incubation period. Studies of cellular influx, as a function of increasing 3-O- $\left[{ }^{14} \mathrm{C}\right] \mathrm{MeG}$ concentrations incubated, revealed saturation kinetics (criterion of carrier-mediated transport) with a $K_{\mathrm{m}}$ of $4.2 \pm 0.4 \mathrm{mM}$ and $V_{\max }$ of $146 \pm 19 \mathrm{nmol} \times \mathrm{min}^{-1}$ per $10^{6}$ cells.

To determine the cellular uptake rate of a substance and not the fraction of ligand, which is merely bound to the plasma membrane, the uptake reaction has to be stopped after certain incubation periods and surface bound but not transported ligand should be removed. For all oleate/albumin solutions employed, it was demonstrated that at $4^{\circ} \mathrm{C}$ no translocation of fatty acids across the plasma membrane occurred. This was derived from the observation, that at $4^{\circ} \mathrm{C}$ no increase in cell associated $\left[{ }^{3} \mathrm{H}\right]$ oleate was detectable over the entire incubation period. Accordingly, the use of phloretin as additional inhibitor of cellular transport processes $(1-3,30)$ was not necessary. Therefore, in this study the addition of $3 \mathrm{ml}$ ice-cold $0.5 \%$ albumin to 200- $\mu$ l aliquots of the incubation system was used to stop cellular influx and efflux, and to remove membrane bound fatty acids. The effectiveness of this stop/chase solution was evaluated in studies, where $25-\mu \mathrm{l}$ aliquots of the cardiomyocyte suspension $\left(2 \times 10^{6}\right.$ cells $\left./ \mathrm{ml}\right)$ were incubated with $173 \mu \mathrm{M}\left[{ }^{3} \mathrm{H}\right]$ oleate/albumin $(1: 1)$ in $200 \mu \mathrm{l}$ of the incubation medium for $30 \mathrm{~s}$. Immediately thereafter (zero time) $3 \mathrm{ml}$ of ice-cold $0.5 \%$ albumin in incubation buffer was added and radioactivity remaining with the cells was determined at intervals up to $15 \mathrm{~min}$. During a rapid reequilibration period of maximal $1 \mathrm{~min} 47 \pm 4 \%$ of the cell-associated radioactivity observed immediately after the 30 -s incubation period was removed. However, over the next $15 \mathrm{~min}$ no further loss of cellular $\left[{ }^{3} \mathrm{H}\right]$ oleate was detectable. The suggestion that the initial loss of radioactivity observed in presence of $0.5 \%$ albumin represents $\left[{ }^{3} \mathrm{H}\right]$ oleate effectively chased off membrane binding sites was supported by the observation that almost identical amounts of $\left[{ }^{3} \mathrm{H}\right]$ oleate were rapidly removed when even higher concentrations of albumin were employed in the stop solution. Furthermore, incubation of cardiomyocytes with $\left[{ }^{3} \mathrm{H}\right]$ oleate at $4^{\circ} \mathrm{C}$, a condition where no transport but membrane binding of ligands is to be expected, only $44 \pm 3 \%$ of the values of cell associated radioactivity at $37^{\circ} \mathrm{C}$ were obtained. Subsequent addition of $0.5 \%$ albumin $\left(4^{\circ} \mathrm{C}\right)$ as stop/chase solution led to a $>90 \%$ loss of this membrane bound $\left[{ }^{3} \mathrm{H}\right]$ oleate. Stop of cellular transport and removal of plasma membrane bound $\left[{ }^{3} \mathrm{H}\right]-$ oleate achieved by $0.5 \%$ albumin $\left(4^{\circ} \mathrm{C}\right)$ could also be demonstrated for the other oleate:albumin complexes employed in the study.

Uptake as a function of the external fatty acid concentration. Uptake of $\left[{ }^{3} \mathrm{H}\right]$ oleate was examined at various unbound oleate concentrations in the incubation medium. The unbound oleate concentration was modulated without exceeding its solubility $(31,32)$ by incubation of a fixed concentration of $173 \mu \mathrm{M}\left[{ }^{3} \mathrm{H}\right]$ oleate bound to varying concentrations of albumin, or by incubation of a fixed concentration of albumin and increasing concentrations of $\left[{ }^{3} \mathrm{H}\right]$ oleate, such that the oleate/ albumin molar ratio varied between $0.25: 1$ up to $2: 1$. This 
provided a range of calculated unbound oleate concentrations of $22-401 \mathrm{nM}$.

For determination of the actual translocation process of fatty acids across the plasma membranes of cardiomyocytes it is essential to analyze their unidirectional cellular influx rates, which were defined as the maximal and linear initial uptake phases. Therefore, the time course of $\left[{ }^{3} \mathrm{H}\right]$ oleate uptake at all oleate/albumin molar ratios was examined at $37^{\circ} \mathrm{C}$. For each oleate/albumin complex it was shown that over the initial 30-s incubation period uptake was maximal and linear, while it gradually decreased thereafter as a result of beginning cellular efflux (Fig. 1; illustrated is a representative experiment with $173 \mu \mathrm{M}\left[{ }^{3} \mathrm{H}\right]$ oleate/albumin [1:1]). The maximal initial uptake phase was taken as a measure of cellular fatty acid influx that was largely independent of intracellular fatty acid metabolism, since after 30 s only $16 \pm 5 \%$ of the intracellular fatty acids were recovered in the esterified form and fatty acid oxidation was not detectable.

Determination of this cellular influx rate as a function of increasing external fatty acid concentrations can distinguish simple diffusion, which is a linear relationship, from transport, which is a saturable process. As shown in Fig. 2, with increasing oleate/albumin molar ratio and thus increasing unbound oleate in the medium initial uptake followed saturation kinetics with a $K_{\mathrm{m}}$ of $78.4 \pm 5.7 \mathrm{nM}$ and a $V_{\max }$ of $1.91 \pm 0.23$ $\mathrm{nmol} \times \mathrm{min}^{-1}$ per $10^{6}$ cardiomyocytes. Uptake was not limited by the oleate/albumin dissociation rates, since they are at least 100 -fold faster than the observed uptake rates at all oleate concentrations studied (33). Furthermore, maximal uptake over the initial 30-s incubation period never exceeded $2 \%$ of the incubated substrate, and the unbound monomeric oleate concentration in the medium was well below the critical concentration for the formation of micelles $(31,32)$, indicating that the apparent saturation kinetics were real and did not reflect substrate depletion. Overlap of the $\left[{ }^{3} \mathrm{H}\right]$ oleate uptake curves, obtained by varying either the oleate or albumin concentration in the incubation system, demonstrates that diffusional gradients due to the differing concentrations of albumin are of no significance under the experimental conditions employed. This observation of saturable fatty acid uptake kinetics was considered to be a criterion of a carrier-mediated transport mechanism.

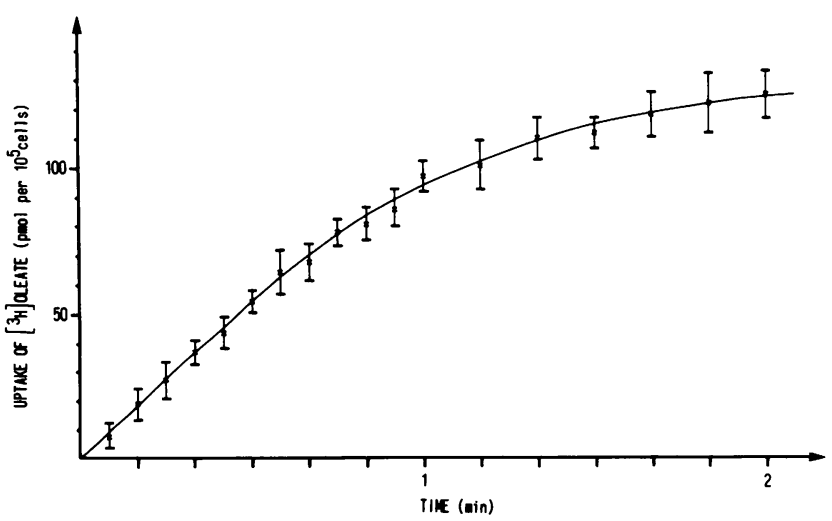

Figure 1. Time course of $\left[{ }^{3} \mathrm{H}\right]$ oleate uptake. $173 \mu \mathrm{M}\left[{ }^{3} \mathrm{H}\right]$ oleate/ albumin (1:1) in $1 \mathrm{ml}$ PBS were incubated at $37^{\circ} \mathrm{C}$ with $125 \mu \mathrm{l}$ of isolated cardiomyocytes $\left(2 \times 10^{6}\right.$ cells $\left./ \mathrm{ml}\right)$. At the times indicated uptake was terminated as described. Values are means $\mathbf{S D}$ of three replicate experiments.

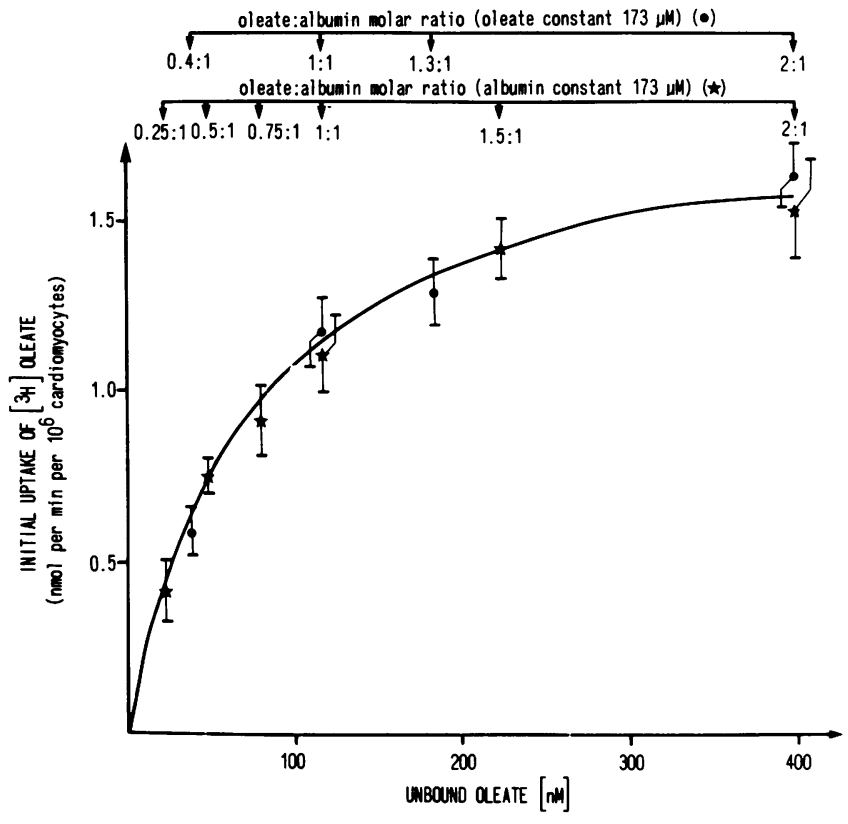

Figure 2. Initial uptake rate of $\left[{ }^{3} \mathrm{H}\right]$ oleate as a function of the unbound oleate concentration in the medium. Isolated cardiomyocytes $\left(0.25 \times 10^{6}\right.$ cells) were incubated in $1 \mathrm{ml}$ at $37^{\circ} \mathrm{C}$ with a fixed concentration of $173 \mu \mathrm{M}\left[{ }^{3} \mathrm{H}\right]$ oleate bound to various concentrations of albumin or with various concentrations of $\left[{ }^{3} \mathrm{H}\right]$ oleate $(43-346 \mu \mathrm{M})$ bound to a fixed concentration of albumin. The unbound fatty acid concentration was calculated as described in Methods. The initial uptake rate was determinated from the linear slopes of the cumulative uptake curves over the initial 30-s incubation period. Values are means $\pm S D$ of three replicate experiments. The kinetic parameters were generated from a weighted least-squares fit of the individual data points from each experiment to a rectangular hyperbola $\left(K_{\mathrm{m}}\right.$ $78.4 \pm 5.4 \mathrm{nM} ; V_{\max } 1.91 \pm 0.23 \mathrm{nmol} \times \min ^{-1}$ per $10^{6}$ cardiomyocytes).

Further characterization of oleate uptake by isolated cardiomyocytes. Temperature dependency of fatty acid transport was determined by incubation of $173 \mu \mathrm{M}\left[{ }^{3} \mathrm{H}\right]$ oleate/albumin (1:1). The initial rate of oleate uptake was maximal at $37^{\circ} \mathrm{C}$ $\left(1.14 \pm 0.13 \mathrm{nmol} \times \min ^{-1}\right.$ per $10^{6}$ cells), a significantly slower influx was observed at $22^{\circ} \mathrm{C}\left(0.73 \pm 0.16 \mathrm{nmol} \times\right.$ min $^{-1}$ per $10^{6}$ cells, $P<0.001)$ and no transport was detectable at $4^{\circ} \mathrm{C}$.

Since calcium is an important intracellular regulator, also affecting plasma membrane transport processes $(34,35)$, uptake of $\left[{ }^{3} \mathrm{H}\right]$ oleate was analyzed in presence of $1 \mathrm{mM} \mathrm{CaCl}_{2}$ in the medium. Incubation of $173 \mu \mathrm{M}\left[{ }^{3} \mathrm{H}\right]$ oleate, bound to albumin in a molar ratio of $1: 1$ and $2: 1$, revealed in presence of 1 $\mathrm{mM} \mathrm{CaCl} 2$ uptake rates of $1.19 \pm 0.20$ and $1.53 \pm 0.18 \mathrm{nmol}$ $\times \min ^{-1}$ per $10^{6}$ cells, respectively. These uptake values were not statistically different to those observed in absence of $\mathrm{Ca}$ (Fig. 2, $P>0.05$ ), indicating that presence of $1 \mathrm{mM} \mathrm{CaCl}_{2}$ has no significant influence on fatty acid transport in isolated cardiomyocytes.

Furthermore, the initial rate of oleate uptake was determined after pretreatment of cardiomyocytes with the $\mathrm{Na}^{+} / \mathrm{K}^{+}$-ATPase inhibitor ouabain. These experiments were again performed in presence and absence of $1 \mathrm{mM} \mathrm{CaCl}_{2}$. In absence of $1 \mathrm{mM} \mathrm{CaCl} 2$ incubation of $173 \mu \mathrm{M}\left[{ }^{3} \mathrm{H}\right]$ oleate/ albumin (2:1) with cardiomyocytes pretreated with $2 \mathrm{mM}$ ouabain revealed a $38 \%$ inhibition of the initial rate of uptake $\left(1.02 \pm 0.18\right.$ vs. $1.64 \pm 0.13 \mathrm{nmol} \times \min ^{-1}$ per $10^{6}$ cells in controls not pretreated with ouabain, $P>0.001$ ). Similarly, in the 
Table I. Sarcolemma Marker Enzyme Activities in the Homogenate and the Plasma Membrane Fraction

\begin{tabular}{cccc}
\hline \multicolumn{1}{c}{ Enzyme } & Homogenate & $\begin{array}{c}\text { Plasma } \\
\text { membranes }\end{array}$ & Enrichment \\
\hline $\mathrm{Na}^{+} / \mathrm{K}^{+}$-ATPase & $0.91 \pm 0.38$ & $39.3 \pm 5.2$ & 43 \\
$\mathrm{~K}^{+}$-p-nitrophenyl & & & \\
$\begin{array}{c}\text { phosphatase } \\
\text { 5'-Nucleotidase }\end{array}$ & $0.14 \pm 0.05$ & $7.84 \pm 1.06$ & 56 \\
& $0.31 \pm 0.06$ & $3.87 \pm 0.81$ & 13 \\
\hline
\end{tabular}

(Data are given as mean \pm SD of five representative preparations. Specific activities are reported as micromoles per milligram.

presence of $1 \mathrm{mM} \mathrm{CaCl}$ the initial uptake was also inhibited by $32 \%\left(1.06 \pm 0.12\right.$ vs. $1.56 \pm 0.21 \mathrm{nmol} \times \min ^{-1}$ per $10^{6}$ cells in controls, $P>0.001$ ).

In additional studies the initial rate of oleate uptake was examined in absence of sodium, by isoosmotic replacement of $\mathrm{NaCl}$ with sucrose, $\mathrm{LiCl}$, choline chloride or $\mathrm{KCl}$ in the incubation medium. However, after a 20 -min preincubation period of cardiomyocytes in Na-free medium, the viability of the cells dropped markedly, as evident by the complete disappearance of the characteristic rod-shaped cell morphology and the observation that $<80 \%$ of the cells excluded trypan blue. These effects were seen in presence as well as in absence of 1 $\mathrm{mM} \mathrm{CaCl}_{2}$ in the medium. Therefore, the apparent inhibition of $\left[{ }^{3} \mathrm{H}\right]$ oleate uptake by $62 \%$ in the absence of $\mathrm{Na}$ compared to the presence of $\mathrm{Na}$ was considered as a nonspecific effect due to the marked decrease in cellular viability.

Binding of $\left[{ }^{3} \mathrm{H}\right]$ oleate to isolated plasma membranes. Since the initial step in any carrier-mediated uptake process represents binding of the ligand to specific membrane binding sites, the interaction of isolated cardiac plasma membranes with $\left[{ }^{3} \mathrm{H}\right]$ oleate was examined.

Characterization of the isolated sarcolemma fraction. Transmission electron microscopy of the cardiac plasma membrane fraction revealed a homogeneous preparation of vesicular membrane structures with diameters ranging from 0.06 to $0.15 \mu \mathrm{m}$. Contaminating membranes from organelles other than plasma membranes were minimal. Accordingly, sarcolemma marker enzymes were significantly enriched in these preparations (Table I), whereas marker enzyme activities for mitochondria, endoplasmatic reticulum, and lysosomes were not elevated in the plasma membrane fraction compared to the homogenate.

Aliquots of these highly enriched cardiac plasma membrane fractions (100 $\mu$ g protein) were incubated with $4.54 \mu \mathrm{M}$ $\left[{ }^{3} \mathrm{H}\right]$ oleate bound to albumin in various molar ratios and binding was examined as a function of the calculated unbound oleate concentration in the medium. With increasing unbound oleate concentrations incubated binding to the membranes revealed saturation kinetics with a $K_{\mathrm{D}}$ of $42.3 \pm 7.8 \mathrm{nM}$ (Fig. 3). Binding was significantly $(P<0.001)$ reduced after heat denaturation of the membranes as well as after pretreatment of the membranes with trypsin (Fig. 4).

Isolation of a fatty acid binding membrane protein. The demonstration of saturable, trypsin inhibitable binding suggested that high affinity binding is due to an intrinsic membrane protein. This suggestion was pursued by application of $300 \mathrm{mg}$ Triton X-100 solubilized proteins from rat myocardial plasma membranes to affinity chromatography over oleatecoupled agarose. SDS-PAGE of the urea eluate of this column revealed a single $40-\mathrm{kD}$ protein (Fig. 5). On gel filtration over an HPLC column this protein comigrated with tracer doses of $\left[{ }^{3} \mathrm{H}\right]$ oleate, $\left[{ }^{14} \mathrm{C}\right]$ linoleate, $\left[{ }^{14} \mathrm{C}\right]$ arachidonate, and $\left[{ }^{3} \mathrm{H}\right]-$ palmitate but not with other complex lipids such as $\left[{ }^{14} \mathrm{C}\right]-$ phosphatidylcholine or cholesteryl- $\left[{ }^{14} \mathrm{C}\right]$ oleate nor with $\left[{ }^{3} \mathrm{H}\right]-$ glucose, suggesting its specific high affinity for various monomeric long-chain fatty acids.

Furthermore, an antibody to this protein was raised in rabbits. In double immunodiffusion studies the antibody to the heart fatty acid binding membrane protein produced a single precipitin line between the purified protein, the mixture of solubilized membrane proteins and whole tissue homoge-

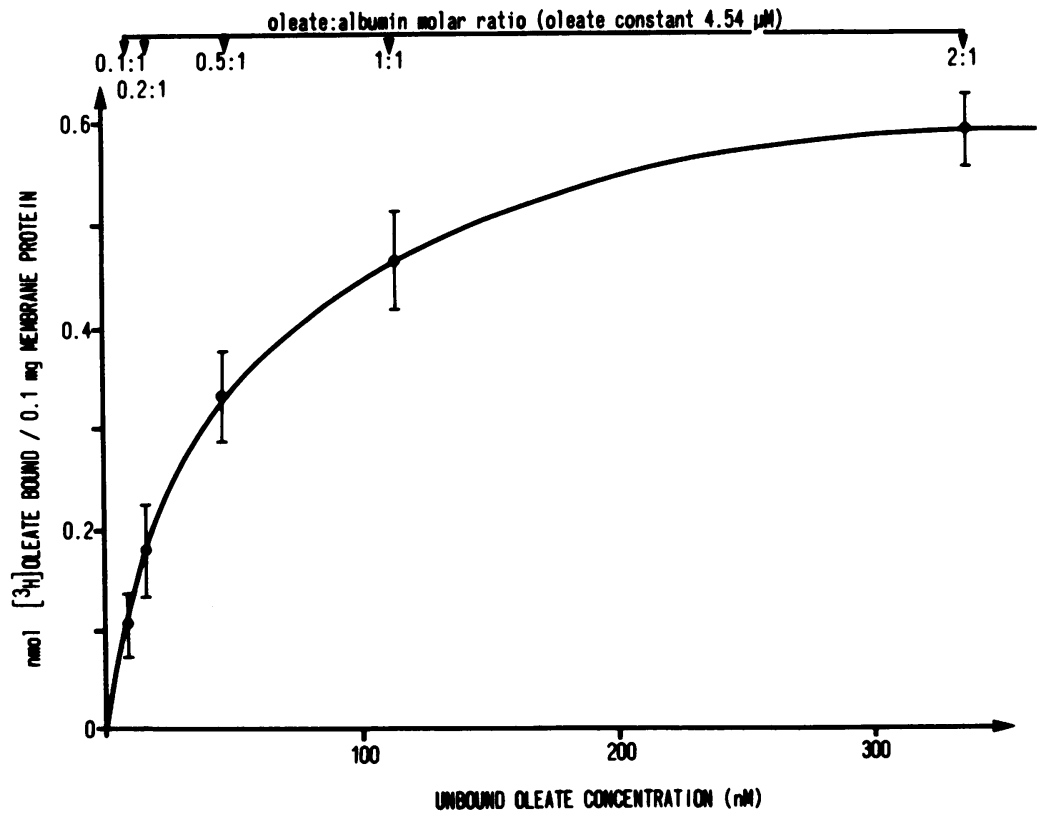

Figure 3. Binding of $\left[{ }^{3} \mathrm{H}\right]$ oleate to isolated plasma membranes of cardiomyocytes. Aliquots of cardiac plasma membrane fractions ( $100 \mu \mathrm{g}$ protein) were incubated at room temperature in a final volume of $400 \mu$ l with $4.54 \mu \mathrm{M}\left[{ }^{3} \mathrm{H}\right]$ oleate bound to albumin in various molar ratios. The unbound oleate concentration was calculated as described in Methods. After incubation for 10 min equilibrium binding to the plasma membranes was assessed by a vacuum filtration assay. Values are means $\pm S D$ of three replicate experiments. The binding parameters were generated from a weighted least-squares fit of the individual data points from each experiment to a rectangular hyperbola $\left(K_{\mathrm{D}} 42.3 \pm 7.8 \mathrm{nM}\right.$; maximal binding capacity $0.682 \pm 0.104 \mathrm{nmol} / 0.1 \mathrm{mg}$ membrane protein). 


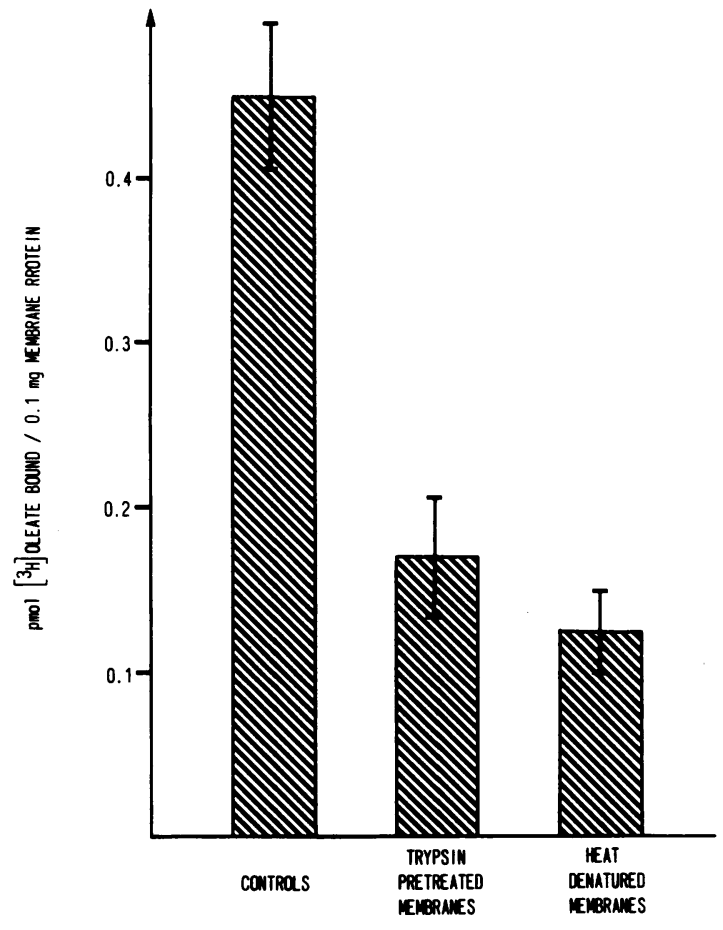

Figure 4. Effect of trypsin pretreatment and heat denaturation on binding of $\left[{ }^{3} \mathrm{H}\right]$ oleate to plasma membranes of cardiomyocytes. 4.54 $\mu \mathrm{M}\left[{ }^{3} \mathrm{H}\right]$ oleate/albumin (1:1) was incubated with $100 \mu \mathrm{g}$ membrane protein aliquots of native, trypsin-pretreated, or heat-denatured plasma membranes of cardiomyocytes (prepared as described in Methods). After incubation for $10 \mathrm{~min}$, binding was assessed by a vacuum filtration assay. Values are means $\pm \mathrm{SD}$ of three replicate experiments.

nates of the heart and liver. No reactivity was observed between this antibody and rat albumin, whole rat serum, and concentrated rat heart and liver cytosol. Immunoblot analysis of this antibody in dilutions of 1:1,000 to 1:50 with solubilized plasma membrane proteins and whole tissue homogenates of

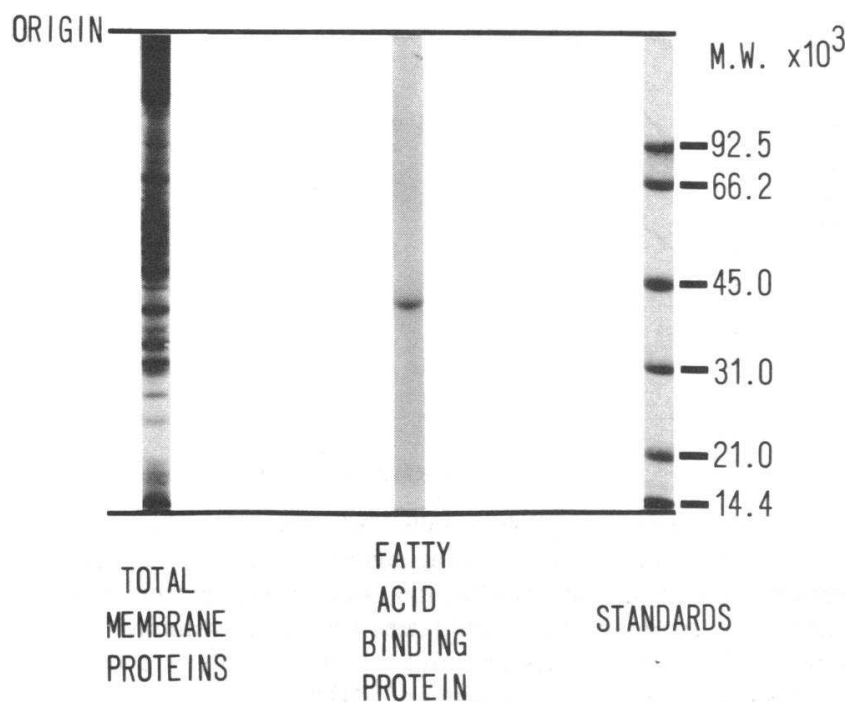

Figure 5. SDS-polyacrylamide gel patterns of the total solubilized cardiac plasma membrane proteins and a single $40-\mathrm{kD}$ fatty acid binding membrane protein isolated by affinity chromatography of cardiac plasma membranes over oleate-coupled agarose. heart and liver identified a single $40-\mathrm{kD}$ protein in all preparations. Identical results were obtained when the antibody to the liver fatty acid binding membrane protein (19) was employed. It indicates that both $40-\mathrm{kD}$ fatty acid binding membrane proteins isolated from liver (19) and heart share antigenic determinants.

By immunofluorescence studies with this monospecific antibody to the myocardial fatty acid binding membrane protein a predominant staining of the plasma membranes of cardiomyocytes, particularly of the intercalated disks was evident (Fig. 6). Absorption of the antibody with purified antigen or incubation with the preimmune serum abolished the membrane staining pattern.

Functional significance of the fatty acid binding membrane protein. To evaluate the functional significance of the membrane fatty acid binding protein, the effect of the monospecific antibody to this protein on fatty acid binding to myocardial plasma membranes was examined. In presence of 10-200 $\mu \mathrm{g}$ of the IgG fraction of the antiserum, membrane binding of fatty acids progressively decreased with maximal inhibition of binding at $100 \mu \mathrm{g}$ of the IgG fraction per $100 \mu \mathrm{g}$ membrane protein. Addition of $>100 \mu \mathrm{g}$ of the IgG fraction did not further increase inhibition of binding. Studies of equilibrium binding as a function of the incubated unbound oleate concentration revealed a significant reduction of the maximal binding capacity by the antibody $(0.148 \pm 0.039 \mathrm{nmol} / 0.1 \mathrm{mg}$ membrane protein) compared to control incubations in presence of the IgG-fraction of the preimmune serum $(0.632 \pm 0.097 \mathrm{nmol} / 0.1 \mathrm{mg}$ membrane protein, $P<0.001)$ (Fig. 7). No statistical difference of the $K_{\mathrm{D}}$ values was evident $(39.5 \pm 4.1 \mathrm{nM}$ vs. $42.4 \pm 3.3 \mathrm{nM}$ in controls, $P>0.05$ ), indicating that the antibody acts predominantly as noncompetitive inhibitor.

The suggestion that this membrane fatty acid binding protein might also be responsible for the translocation of fatty acids across the plasma membrane into the intracellular space was substantiated, when the effect of the monospecific antibody to this protein on cellular influx kinetics was analyzed. When oleate influx by cardiomyocytes pretreated with the IgG fraction of the antiserum was compared with that of a control preparation pretreated with the $\mathrm{IgG}$ fraction of the preimmune serum, a significant inhibition of initial uptake velocity by the antibody was demonstrated. This inhibition was dependent on the concentration of the antibody, reaching a maximum at 100 $\mu \mathrm{g} \mathrm{IgG/incubation.} \mathrm{Studies} \mathrm{of} \mathrm{influx} \mathrm{as} \mathrm{a} \mathrm{function} \mathrm{of} \mathrm{the} \mathrm{incu-}$ bated unbound oleate concentration revealed a predominant noncompetitive inhibition of uptake by the anti-fatty acid binding protein (Fig. 8). This was evident by a marked decrease of $V_{\max }\left(1.183 \pm 0.107 \mathrm{nmol} \times \mathrm{min}^{-1}\right.$ per $10^{6}$ cells in antibody-pretreated cells vs. $2.021 \pm 0.236 \mathrm{nmol} \times$ min $^{-1}$ per $10^{6}$ cells in controls, $P<0.001$ ), but no statistical difference in the obtained $K_{\mathrm{m}}$ values $(76 \pm 5 \mathrm{nM}$ vs. $75 \pm 8 \mathrm{nM}$ in controls, $P$ $>0.05$ ).

To evaluate whether the inhibition of oleate uptake by the antibody marks a specific effect on the fatty acid uptake system or represents a more general interference with membrane transport processes, the effect of this antibody on cellular influx of 3-O-[ $\left[{ }^{14} \mathrm{C}\right.$-methyl]-D-glucose was analyzed. The uptake parameters observed with cardiomyocytes pretreated with the IgG-fraction of the antiserum to the fatty acid binding membrane protein $\left(K_{\mathrm{m}} 4.0 \pm 0.5 \mathrm{mM} ; V_{\max } 154 \pm 14 \mathrm{nmol} \times \mathrm{min}^{-1}\right.$ per $10^{6}$ cells) or with the IgG-fraction of the preimmune serum 


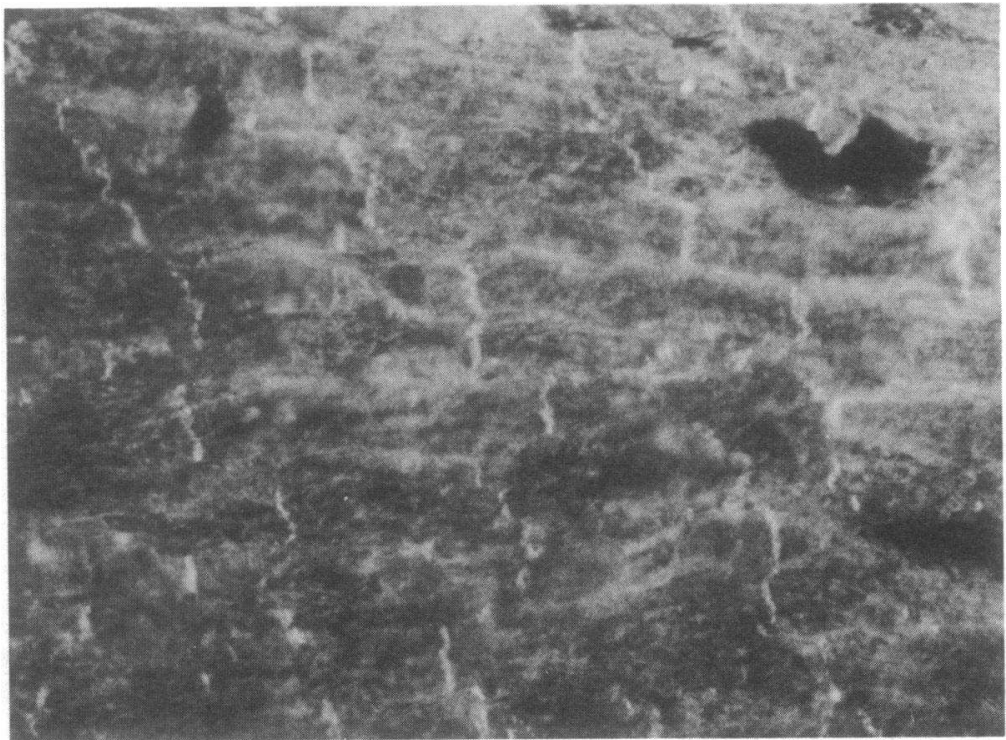

Figure 6. Indirect immunofluorescence staining of plasma membranes of cardiomyocytes in normal rat heart sections after incubation with a rabbit antiserum to the membrane fatty acid binding protein.
( $K_{\mathrm{m}} 4.4 \pm 0.3 \mathrm{mM} ; V_{\max } 135 \pm 21 \mathrm{nmol} \times \min ^{-1}$ per $10^{6}$ cells) did not significantly differ $(P>0.05)$. This indicates that the anti-membrane fatty acid binding protein has no effect on glucose transport, and that the transport competence for glucose is not altered by the IgG pretreatment procedure of the cells.

\section{Discussion}

The observation that influx of oleate into isolated cardiomyocytes demonstrates saturation kinetics and temperature dependency is compatible with the hypothesis of a membrane

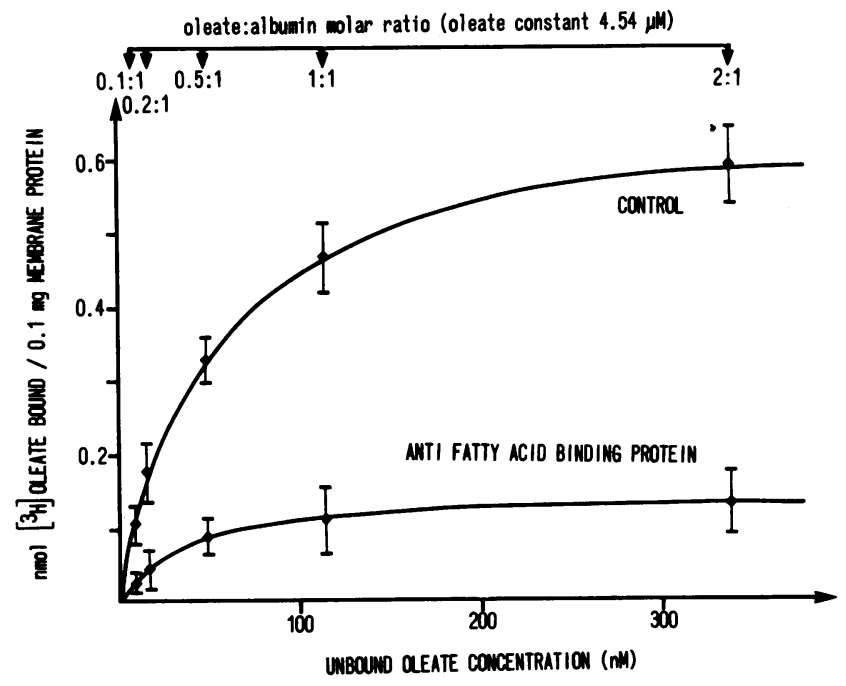

Figure 7. Inhibition of the binding of $\left[{ }^{3} \mathrm{H}\right]$ oleate to isolated cardiac plasma membranes by the monospecific rabbit antibody to the rat heart fatty acid binding membrane protein. Aliquots of cardiac plasma membrane fractions ( $100 \mu \mathrm{g}$ protein) were incubated in the presence of $100 \mu \mathrm{g}$ of the IgG fraction of the antiserum to the membrane fatty acid binding protein or of the preimmune serum as controls. Binding to the membranes was plotted as a function of the unbound oleate concentration in the medium, which was modulated by incubation of $4.54 \mu \mathrm{M}\left[{ }^{3} \mathrm{H}\right]$ oleate bound to albumin in various molar ratios. Values are means \pm SD of three replicate experiments. carrier-mediated uptake mechanism. A saturable transport component of myocardial fatty acid uptake was already proposed by earlier studies of Samuel et al. (36) and Paris et al. (37). On the other hand, De Grella and Light $(38,39)$ interpreted this saturable uptake phenomenon as a result of intracellular fatty acid metabolism. In fact, in those earlier studies net accumulation of fatty acids within the cells was determined and it was not differentiated between the fatty acid metabolism and cellular influx component. Therefore, in the present study the initial rates of fatty acid uptake were determined. They were calculated from the slopes of the cumulative uptake

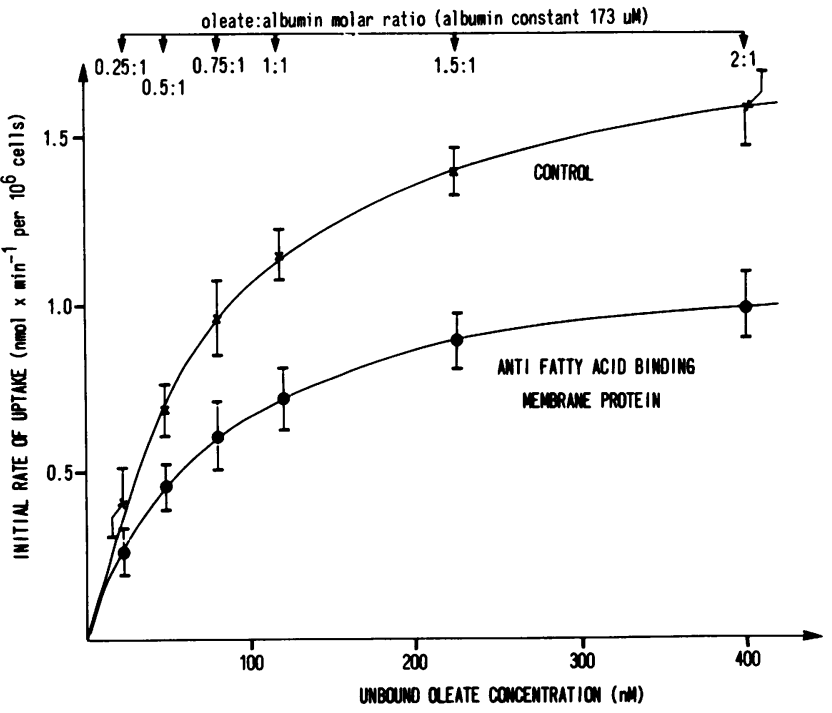

Figure 8. Inhibition of $\left[{ }^{3} \mathrm{H}\right]$ oleate influx into isolated cardiomyocytes by the anti-cardiac fatty acid binding membrane protein. Cells pretreated with $100 \mu \mathrm{g}$ of the IgG-fraction of the antiserum were compared to a control preparation pretreated with the preimmune serum. $125 \mu$ l of the cell suspensions $\left(2 \times 10^{6}\right.$ cells $\left./ \mathrm{ml}\right)$ were incubated with increasing concentrations of $\left[{ }^{3} \mathrm{H}\right]$ oleate $(43-346 \mu \mathrm{M})$ bound to a fixed concentration of albumin at $37^{\circ} \mathrm{C}$. Illustrated are the initial uptake rates as a function of the calculated unbound oleate concentrations in the incubation media. Values are means \pm SD of three replicate experiments. 
curves, which were maximal and linear over the initial 30-s incubation period. This initial uptake phase predominantly represents the unidirectional cellular influx rate, which is independent of intracellular fatty acid metabolism, since more than $80 \%$ of the cell associated fatty acids were still recovered in the unesterified form after $30 \mathrm{~s}$. This cellular fatty acid influx component was temperature dependent and revealed saturation kinetics with a $K_{\mathrm{m}}$ of $78 \mathrm{nM}$ and a $V_{\max }$ of $1.9 \mathrm{nmol}$ $\times \min ^{-1}$ per $10^{6}$ cardiomyocytes, which are similar to the kinetic parameters obtained in hepatocytes $(2,3)$. The $K_{\mathrm{m}}$ appears to be well above the physiologic concentration of unbound fatty acids in the plasma $(10,11)$. Based on estimations of cellular fatty acid metabolism in isolated cardiomyocytes (39) and the perfused heart (40), the $V_{\max }$ value determined here provides a sufficient reserve capacity for fatty acid influx to meet the energy requirement of cardiomyocytes, even under excercise conditions.

The suggestion of a membrane carrier-mediated uptake system was further substantiated by identification of high affinity membrane binding sites for fatty acids $\left(K_{\mathrm{D}} 42 \mathrm{nM}\right)$. Moreover, a single specific membrane protein with high affinity to various long chain fatty acids was isolated. This $40-\mathrm{kD}$ protein shares antigenic determinants with the liver fatty acid binding protein (19). However, whether these are in fact identical proteins or just related, similar to the different cytosolic fatty acid binding proteins isolated from liver and heart (41, 42), remains to be established. The physiologic significance of this membrane protein as carrier in the myocardial uptake process of fatty acids is evident, since influx of $\left[{ }^{3} \mathrm{H}\right]$ oleate was significantly inhibited by a monospecific antibody to this protein, whereas uptake of glucose remained unaltered. These data indicate that fatty acid uptake by cardiomyocytes is at least in part mediated by a specific $40-\mathrm{kD}$ membrane protein. It seems attractive to speculate whether cellular influx of this major class of energy-yielding substrates may be regulated by such a receptor protein.

The driving forces mediating the cellular entry of fatty acids in cardiomyocytes are still unclear. Similar to hepatocellular fatty acid uptake it could be assumed that fatty acid transport across myocardial plasma membranes might also be driven by an active, $\mathrm{Na}^{+}$-dependent, potential-sensitive translocation process, which was established in studies with basolateral rat liver plasma membrane vesicles (18). In fact, pretreatment of cardiomyocytes with $2 \mathrm{mM}$ ouabain, which is known to inhibit the $\mathrm{Na}^{+} / \mathrm{K}^{+}$-ATPase, reduced cellular influx of oleate by $38 \%$, suggesting that uptake might be linked to the activity of this enzyme maintaining the physiologic transmembrane $\mathrm{Na}^{+} / \mathrm{K}^{+}$-gradient. However, in the experimental system of isolated cardiomyocytes a more direct evaluation of the effect of $\mathrm{Na}$ depletion on the initial rate of cellular fatty acid uptake was unsuccessful due to a significant drop in cell viability after exposure to a $\mathrm{Na}$-free incubation medium. Therefore, uptake studies with isolated plasma membrane vesicles of cardiomyocytes are planned.

\section{Acknowledgments}

I am grateful to Marion Scheider and Beate Zimmerbeutel for their expert technical assistance. This paper is dedicated to Professor Dr. G. Strohmeyer on his 60 th birthday.

Supported by grant STR 216/2-3 from the Deutsche Forschungsgemeinschaft, Federal Republic of Germany.

\section{References}

1. Stremmel, W., and P. D. Berk. 1986. Hepatocellular influx of ${ }^{14} \mathrm{C}$-oleate reflects membrane transport rather than intracellular metabolism or binding. Proc. Natl. Acad. Sci. USA. 83:3086-3090.

2. Stremmel, W., G. Strohmeyer, and P. D. Berk. 1986. Hepatocellular uptake of oleate is engery-dependent, sodium-coupled and inhibited by an antibody to the liver plasma membrane fatty acid binding protein. Proc. Natl. Acad. Sci. USA. 83:3584-3588.

3. Stremmel, W., and L. Theilmann. 1986. Selective inhibition of long chain fatty acid uptake in short-term cultured rat hepatocytes by an antibody to the rat liver plasma membrane fatty acid binding protein. Biochim. Biophys. Acta. 877:191-197.

4. Powell, T., D. A. Terrar, and V. W. Twist. 1980. Electrical properties of individual cells isolated from adult rat ventricular myocardium. J. Physiol. 302:131-153.

5. Piper, H. M., I. Probst, P. Schwartz, F. J. Hütter, and P. G. Spieckermann. 1982. Culturing of calcium stable adult cardiac myocytes. J. Mol. Cell. Cardiol. 14:397-412.

6. Piper, H. M. 1985. Isolierte adulte Herzmuskelzellen als Myokardmodell. Thieme Copythek, Georg Thieme Verlag, Stuttgart, New York. 212.

7. Lamprecht, W., and J. Trautschold. 1963. Adenosine-5'-triphosphate. Determination with hexokinase and glucose-6-phosphate dehydrogenase. In Methods of Enzymatic Analysis. H. U. Bergmeyer, editor. Academic Press, New York. 543-557.

8. Bergmeyer, H. U., E. Bernt, and B. Hess. 1963. Lactic dehydrogenase. In Methods of Enzymatic Analysis. H. U. Bergmeyer, editor. Academic Press, New York. 736-741.

9. Noda, L., S. Kuby, and H. Lardy. 1955. ATP-creatine transphosphorylase. In Methods in Enzymology. S. P. Colowick and N. O. Kaplan, editors. Vol. 2. Academic Press, New York. 605-616.

10. Wosilait, W. D., and P. Nagy. 1976. A method of computing drug distribution in plasma using stepwise association constants. Clofibrate acid as an illustrative example. Comput. Prog. Biomed. 6:142148.

11. Spector, A. A., J. E. Fletcher, and J. D. Ashbrook. 1971. Analysis of long chain fatty acid binding to bovine serum albumin by determination of stepwise equilibrium constants. Biochemistry. 10:32293232.

12. Van Alstyne, E., R. M. Burch, R. G. Knickelbein, R. T. Hungerford, E. J. Gower, J. G. Webb, S. L. Poe, and G. E. Lindenmayer. 1980. Isolation of sealed vesicles highly enriched with sarcolemma markers from canine ventricle. Biochim. Biophys. Acta. 602:131-143.

13. Lowry, O. H., N. J. Rosebrough, A. Lewis-Farr, and R. J. Randall. 1951. Protein measurement with the Folin phenol reagent. $J$. Biol. Chem. 193:265-279.

14. Baudhuin, P., P. Evrard, and J. Berthet. 1967. Electron microscopy examination of subcellular fractions. I. The preparation of representative samples from suspensions of particles. J. Cell Biol. 32:181191.

15. Schwartz, A., J. C. Allen, and S. Harigaya. 1969. Possible involvement of cardiac $\mathrm{Na}^{+}, \mathrm{K}^{+}$-adenosine triphosphatase in the mechanism of action of cardiac glycosides. J. Pharmacol. Exp. Ther. 168:31-41.

16. Skou, J. C. 1974. Effect of ATP on the intermediary steps of the reaction of the $\left(\mathrm{Na}^{+}\right.$plus $\left.\mathrm{K}^{+}\right)$-dependent enzyme system. 3. Effect on the p-nitrophenylphosphatase activity of the system. Biochim. Biophys. Acta. 339:258-272.

17. Mitchell, R. H., and J. N. Hawthorne. 1965. The site of diphosphoinositide synthesis in rat liver. Biochem. Biophys. Res. Commun. 21:333-338.

18. Stremmel, W. 1987. Translocation of fatty acids across the basolateral rat liver plasma membrane is driven by an active potential-sensitive sodium-dependent transport system. J. Biol. Chem. 262:6284-6289.

19. Stremmel, W., G. Strohmeyer, F. Borchard, S. Kochwa, and P. D. Berk. 1985. Isolation and partial characterization of a fatty acid 
binding protein in rat liver plasma membranes. Proc. Natl. Acad. Sci. USA. 82:4-8.

20. Neville, D. M., Jr. 1971. Molecular weight determination of protein-dodecyl sulfate complexes by gel electrophoresis in a discontinuous buffer system. J. Biol. Chem. 246:6328-6334.

21. Stremmel, W., G. Lotz, C. Niederau, R. Teschke, and G. Strohmeyer. 1987. Iron uptake by rat duodenal mcirovillous membrane vesicles. Evidence for a carrier mediated transport system. Eur. J. Clin. Invest. 17:136-145.

22. Ouchterlony, O. 1958. Diffusion in gel methods. Prog. Allergy. $5: 1-78$.

23. Towbin, H., T. Stachelin, and J. Gordon. 1979. Electrophoretic transfer of proteins from polyacrylamide gels to nitrocellulose sheets: procedure and some applications. Proc. Natl. Acad. Sci. USA. 76:4350-5354.

24. Kochwa, S. 1961. Isoagglutinins associated with $A B O$ erythroblastosis. J. Clin. Invest. 40:874-883.

25. Snedecor, G. W., and W. G. Cochran. 1980. Statistical Methods. The Iowa State University Press, Ames, IA.

26. Cleland, W. W. 1979. Statistical analysis of enzyme kinetic data. Methods Enzymol. 63:103-138.

27. Altschuld, R., L. Gibb, A. Ansel, C. Hohl, F. A. Kruger, and G. P. Brierley. 1980. Calcium tolerance of isolated rat heart cells. $J$. Mol. Cell. Cardiol. 12:1383-1395.

28. Dow, J. W., N. G. L. Harding, and T. Powell. 1981. Isolated cardiac myocytes. II. Functional aspects of mature cells. Cardiovasc. Res. 15:483-514.

29. Gerards, P., W. Graf, and H. Kammermeier. 1982. Glucose transfer in isolated cardiomyocytes of adult rats. J. Mol. Cell Cardiol. 14:141-149.

30. Abumrad, N. A., R. C. Perkins, J. H. Park, and C. R. Park. 1981. Mechanism of long chain fatty acid permeation in the isolated adipocyte. J. Biol. Chem. 259:9183-9191.

31. Klevens, H. B. 1975. Structure and aggregation in dilute solutions of surface active agents. J. Am. Oil Chem. Soc. 30:74-80.
32. Corrin, H. L., H. B. Klevens, and W. D. Harkins. 1946. The determination of critical concentrations for the formation of soap micelles by the spectral behaviour of pinacyanol chloride. J. Chem. Phys. 14:480-486.

33. Weisiger, R. A., J. L. Gollan, and R. K. Ockner. 1982. The role of albumin in hepatic uptake processes. In Progress in Liver Disease. H. Popper and F. Schaffner, editors. Vol. VII. Grune \& Stratton, Inc., New York. 71-75.

34. Langer, G. A. 1982. Sodium-calcium exchange in the heart. Annu. Rev. Physiol. 44:435-559.

35. Putney, J. W. 1979. Stimulus-permeability coupling: role of calcium in the receptor regulation of membrane permeability. Pharmacol. Rev. 30:209-245.

36. Samuel, D., S. Paris, and G. Ailhaud. 1976. Uptake and metabolism of fatty acids and analogues by cultured cardiac cells from chick embryo. Eur. J. Biochem. 64:583-595.

37. Paris, S., D. Samuel, Y. Jaques, C. Gache, A. Franchi, and G. Ailhaud. 1978. The role of serum albumin in the uptake of fatty acids by cultured cardiac cells from chick embryo. Eur. J. Biochem. 83:235-243.

38. De Grella, R. F., and R. J. Light. 1980. Uptake and metabolism of fatty acids by dispersed adult rat heart myocytes. I. Kinetic of homologous fatty acids. J. Biol. Chem. 255:9731-9738.

39. De Grella, R. F., and R. J. Light. 1980. Uptake and metabolism of fatty acids by dispersed adult rat heart myocytes. II. Inhibition by albumin and fatty acid homologous, and the effect of temperature and metabolic reagents. J. Biol. Chem. 255:9739-9745.

40. Evans, J. R., L. H. Opie, and J. C. Shipp. 1963. Mechanism of palmitic acid in perfused rat heart. Am. J. Physiol. 205:766-770.

41. Said, B., and H. Schulz. 1984. Fatty acid binding protein from rat heart. J. Biol. Chem. 259:1155-1159.

42. Glatz, J. F. C., A. M. Janssen, C. C. F. Baerwaldt, and J. H. Veerkamp. 1985. Purification and characterization of fatty acid-binding proteins from rat heart and liver. Biochim. Biophys. Acta. 837:5766. 